\title{
Modeling of an MTBE plume at Pascoag, Rhode Island
}

\author{
A. Myrttinen - T. Boving $\cdot$ O. Kolditz
}

Published online: 26 November 2008

(C) Springer-Verlag 2008

\section{Erratum to: Environ Geol}

\section{DOI 10.1007/s00254-008-1416-8}

Unfortunately two errors occurred in the article. The correct version is given below:

Introduction, line 1: "February 2001" is incorrect, the sentence should say "Fall 2001"

Table 4 Component properties: "foc $0.0005 \%$ " should be unitless i.e. it should say "foc 0.0005 " without the \% sign.

The online version of the original article can be found under doi:10.1007/s00254-008-1416-8.

\footnotetext{
A. Myrttinen ( $\square$ )

Center of Applied Geosciences,

University of Tübingen, Tübingen, Germany

e-mail: anssi.myrttinen@web.de

T. Boving

Department of Geosciences,

University of Rhode Island, Kingston, USA

O. Kolditz

Department of Environmental Informatics,

Helmholtz Centre for Environmental Research,

UFZ, Leipzig, Germany
} 